\title{
ХАРАКТЕРИСТИКА ГОТЕЛЬНОЇ СФЕРИ ЧЕРКАЩИНИ В КОНТЕКСТІ РОЗВИТКУ ТУРИЗМУ В РЕГІОНІ
}

\section{DESCRIPTION OF CHERKASY REGION'S HOTEL INDUSTRY IN THE CONTEXT OF TOURISM SPHERE IN THE REGION}

\author{
Красномовець Вікторія Анатоліївна \\ кандидат економічних наук, доцент, \\ Черкаський національний університет імені Богдана Хмельницького \\ ORCID: https://orcid.org/0000-0001-5806-8348 \\ Дроботова Марина Володимирівна \\ кандидат економічних наук, доцент, \\ Черкаський національний університет імені Богдана Хмельницького \\ ORCID: https://orcid.org/0000-0003-2676-0588
}

Krasnomovets Viktoriia, Drobotova Marina

Bohdan Khmelnytsky National University of Cherkasy

\begin{abstract}
Статтю присвячено питанням особливостей фрункціонування готельної галузі у Черкаській області. Всебічно та ґрунтовно проаналізовано основні показники розвитку готельних підприємств регіону у розрізі їх категорій, місця розташування, особливостей надання основних та додаткових послуг та інших параметрів у контексті розвитку туризму на Черкащині. Охарактеризовано основні готельні комплекси Черкаської області за показниками їх власно наведеної інформації та відгуків на сайтах бронювання. Проведено аналіз розвитку зелених садиб, хостелів та спеціалізованих засобів розміщення в регіоні. У аспекті сприяння розвитку туристичної сфери регіону, проаналізовано стан забезпечення засобами розміщення основних туристичних напрямків за видами туризму в регіоні.
\end{abstract}

Ключові слова: готельна сорера, засоби розміщення, види туризму, Черкаська область.

Статья посвящена вопросам особенностей фрункционирования гостиничной отрасли в Черкасской области. Всесторонне и основательно проанализированы основные показатели развития гостиничных предприятий региона в разрезе их категорий, местоположения, особенностей предоставления основных и дополнительных услуг и других параметров в контексте развития туризма в Черкасской области. Охарактеризованы основные гостиничные комплексы региона за показателями их собственной информации и отзывов на сайтах бронирования. Проведен анализ развития зеленых усадеб, хостелов и специализированных средств размещения в регионе. В аспекте содействия развитию туристической соеры региона проанализировано состояние обеспечения средствами размещения основных туристических направлений по видам туризма в регионе.

Ключевые слова: гостиничная сфера, средства размещения, виды туризма, Черкасская область.

The article is devoted to the peculiarities of the hotel industry in the context of tourism development in Cherkassy region. The main indicators of hotel enterprises development in region on the dynamics of the last few years and indicators of their categories, the number of people who visited and the load factor of the number of tourists per place in hotels are comprehensively and thoroughly analyzed. The hotel sphere of the region is also analyzed according to the location of hotels, peculiarities of providing basic and additional services and other parameters in the context of tourism development in Cherkassy region. The main hotel complexes of Cherkassy region are characterized according to the indicators of their own information and reviews on booking sites. Development of green estates, hostels and specialized accommodation in the region are analyzed. In general, region is good provided with the main types of accommodation. There is one four-star hotel, several three-star hotels, two hotels from the national hotel chain and many hotel complexes, most of which are located along the Dnieper river. The negative point is the lack of a two-star hotel in the regional center and such establishments in large tourist centers of the region (Kaniv, Chyhyryn). Hotels in Cherkasy region are located very unevenly. The cities of Cherkassy and Uman have the largest number of accommodation facilities, while powerful tourist centers, such as Kaniv, Chyhyryn, Zvenigorod - are equipped with hotels and similar 
accommodation not very well. In the system of development of the hotel industry of any level it is especially important to take into account the main trends in the market of tourist services in the country as a whole and the region in particular. The article states that hotels are well equipped with such types of tourism that have developed in the region as: skiing, equestrian, wellness / health tourism, business, beach and other. At the same time, the issue of ensuring the availability of rooms for special categories of people - persons with disabilities remains problematic. The obsolescence of many buildings and the equipment of most hotels in the region are also problematic.

Keywords: hotel industry, accommodation facilities, types of tourism, Cherkasy region.

Постановка проблеми. В сучасних умовах панування ринкових відносин і поглиблення тенденцій глобалізації у всіх сорерах життєдіяльності суспільства значно підвищується роль окремих регіонів в соціально-економічному розвитку багатьох держав світу, підвищується рівень їх самостійності у вирішенні життєво важливих питань. Однією 3 найпотужніших сорер розвитку на регіональному рівні є туризм. А в туристичній галузі критично важливою запорукою успіху $\epsilon$ інфрраструктура, а особливо її готельна складова. Розвиток туристичної індустрії залежить насамперед від наявності зручних готелів, гарних місць для харчування у цьому регіоні та якості обслуговування туристів.

Готельне господарство $€$ основною складовою туристичної інфраструктури та відіграє провідну роль у презентації національного туристичного продукту на світовому ринку туристичних послуг. Упродовж останніх десятиліть сорера національного готельного господарства набуває стрімкого розвитку та потребує розроблення заходів щодо зростання показників ефективності діяльності [1, с. 90].

Водночас, особливо важливо в системі розвитку готельної сфери будь-якого рівня враховувати основні тенденції розвитку ринку туристичних послуг як країни в цілому, так і регіону зокрема.

Аналіз останніх досліджень і публікацій. Теоретичною основою роботи слугували поодинокі наукові дослідження стану розвитку готельної сфрери на Черкащині у публікаціях таких вчених як А. О. Шастун та Л. М. Чепурда. Основою ґрунтовного аналізу стали матеріали державного управління статистики, сайти готелів та інші наукові видання та інтернет-ресурси.

Виділення невирішених раніше частин загальної проблеми. Ґрунтовні дослідження, що стосувалися б питань розвитку готельної інорраструктури у Черкаському регіоні відсутні, відтак пропоноване дослідження $\epsilon$ вельми актуальним.

Формулювання цілей статті - дослідити стан розвитку готельної інфраструктури у розрізі їх категорії, місця розташування, особли- востей надання послуг та інших параметрів основних закладів регіону у контексті розвитку туризму на Черкащині.

Виклад основного матеріалу дослідження. За даними Головного управління статистики у Черкаській області, за підсумками 2019 року, в регіоні функціонувало 55 колективних засобів розміщування (КЗР), 3 них 24 готелі та аналогічні засоби розміщування (готелі, мотелі) [2, с. 7]. Втім карантинні обмеження витримали не всі заклади і у 2020 році їх кількість скоротилася до 43 [3, с. 5]. У загальному потенціалі підприємств готельного господарства в 2019 р. налічувалось 4308 номери, у 2020 році - 3076. Протягом 2019 року у колективних засобах розміщування по всій Черкаській області перебувало 114025 осіб [2, с. 8]. Найбільша кількість (91\%) осіб перебувало у готелях та аналогічних засобах розміщування, найменша ж частка - 0,07\% у інших засобах розміщування [2, с. 10]. Втім, у 2020 році кількість відвідувачів зменшилася майже в 2 рази до 52433 осіб [3, с. 8].

Водночас, дуже низькою залишається кількість іноземців, що перебували у колективних засобах розміщування по Черкаській області: у 2019 році - 4061 осіб, у 2020 році - лише 653. Середня тривалість перебування іноземців у колективних засобах розміщування Черкащини у 2019 році - 2,5 дні, у 2020 - 2,1 день $[2$, c. $12 ; 3$, с. 9].

3-поміж інших областей місце Черкаської області було визначено за порівнянням даних щодо загальної кількості місць у колективних засобах розміщування за регіонами у 2019 році; кількості туристів, обслугованих туроператорами та турагентами, у 2019 році за регіонами та по навантаженню туристів на одне місце у колективних засобах розміщування. Так, у межах наявних 4308 місць у колективних засобах розміщування, всього було зареєстровано 2678 туристів, з яких 20 іноземці. Таким чином, коефіцієнт навантаження кількості туристів на одне місце в КЗР становить 0,62 при середньому значенні по Україні - 2,85, що дозволяє зробити висновок, що в цілому Черкащина у 2019 році, за даними офріційної статистики була цілком 
забезпечена місцями у колективних засобах розміщення з огляду на кількість туристів, що відвідує регіон.

У характеристиці колективних засобів розміщування окремо охарактеризуємо обласний центр. У місті Черкаси прослідковуємо зростання кількості готелів та аналогічних засобів розміщування з 6 у 2018 до 8 одиниць у 2020 році. Надзвичайно позитивною тенденцією, яку відзначаємо як на рівні обласного центру, так і регіону загалом, є поява і збільшення кількості колективних засобів розміщування зі спеціально обладнаними номерами (кімнатами) для осіб з інвалідністю. У Черкасах таких засобів розміщування у 2019 році було 2, в області - 8 [2, с. 3], водночас, їх кількість досі зовсім не достатня.

Проаналізуємо готельну сфреру регіону за базовими параметрами (табл. 1).

У загальній характеристиці готельних закладів області виокремимо кілька особливих рис, які, на нашу думку, варті особливої уваги. Перш за все, зазначимо, що в Черкаській області відсутній заклад готельного господарства категорії 5*. Віднедавна категоризація готелів за «зірками» не $€$ обов'язковою, але водночас, готельні заклади досі широко використовують їі як досить потужний маркетинговий інструмент, а також 3 метою встановлення співпраці з туристичними підприємствами. Найвище значення «зіркової» категорії - 4* має готель «Дніпро» у місті Черкаси. Тризірковими також $є$ готель «Оптима», колишній готель «Апельсин», а нині готель «Cherkasy Palace» (м. Черкаси) та «Княжа Гора» (м. Канів). 26 квітня 2021 року отримав категорію 3* готель «Україна» [22].

Немає також жодного закладу, що входив би до однієї зі світових готельних мереж. Натомість $€$ два готелі, що $€$ частиною національної готельної мережі «Reikartz» - це готель «Reikartz Aquadar» у м. Маньківка та готель «Optima» у м. Черкаси.

Засоби розміщення Черкаської області розташовані вкрай нерівномірно (рис. 1). Найвища їх концентрація знаходиться: в обласному центрі та передмісті Черкас; вздовж головної водної артерії країни - річки Дніпро, що сприяє розвитку водного, риболовецького, пляжного та купального туризму; та у місті Умань, що $є$ перлиною культурно-пізнавального та релігійного туризму.

Окремо зупинимося на додаткових послугах, що їх надають КЗР регіону. Зокрема,

Характеристика основних готельних комплексів Черкаської області

Таблиця 1

\begin{tabular}{|c|c|c|c|}
\hline Назва & Категорія & Місце розташування & Кількість номерів \\
\hline Готель «Дніпро» &  & м. Черкаси & 110 \\
\hline Готель «Optima» & $\star \star \star$ & м. Черкаси & 79 \\
\hline Готель «Україна» & 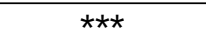 & м. Черкаси & 91 \\
\hline $\begin{array}{l}\text { Готель «Cherkasy Palace» } \\
\text { (колишній «Апельсин») }\end{array}$ & 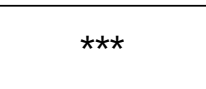 & м. Черкаси & 62 \\
\hline Готель «Нива» & н/д & м. Черкаси & 60 \\
\hline Готель «Черкаси» & н/д & м. Черкаси & н/Д \\
\hline Готель «Вершник» & н/д & м. Черкаси & 21 \\
\hline ГK «Selena Family Resort» & н/д & м. Черкаси & \\
\hline ГK «Perlyna Resort» & н/д & с. Свидівок & \\
\hline$\Gamma \mathrm{K}$ «Riverwood» & н/д & с. Мошни & 36 \\
\hline Готель «Reikartz Aquadar» &  & м. Маньківка & 119 \\
\hline ГК «Водяники» & н/д & с. Водяники & 45 \\
\hline Готель ««Parade Allure» & & м. Жашків & 17 \\
\hline Готель «Княжа Гора» & $\star \star \star$ & М. Канів & н/д \\
\hline Готель «Smile» & ** & м. Умань & $\mathrm{H} / \mathrm{д}$ \\
\hline Готель «Умань Плаза» & н/д & м. Умань & н/д \\
\hline Готель «Застава» & н/Д & м. Умань & н/Д \\
\hline Готель «Меланія» & н/д & м. Умань & н/д \\
\hline Готель «Ломо» & н/д & м. Умань & н/д \\
\hline Готель «Фортеця» & н/Д & м. Умань & н/д \\
\hline
\end{tabular}

н/д - немає даних

Джерело: складено автором на основі даних з відкритих інтернет-джерел [4-21] 


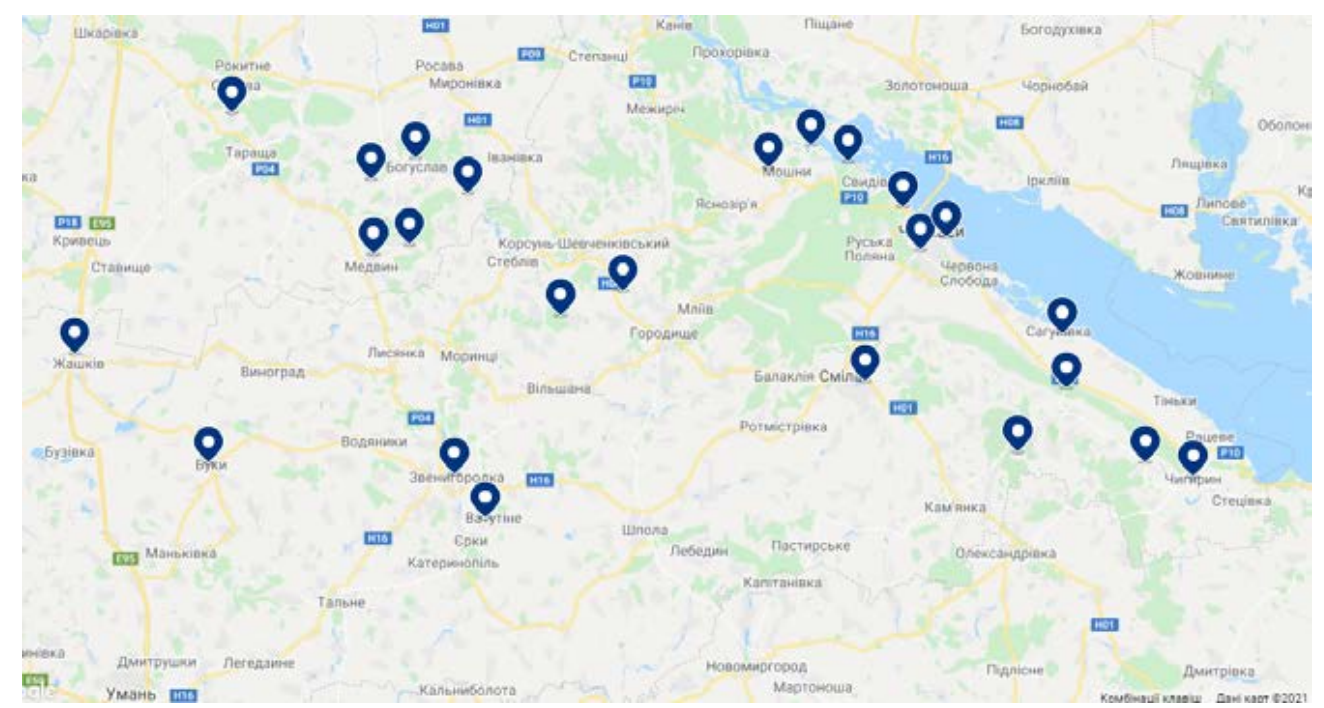

Рис. 1. Розташування закладів готельного господарство Черкаської області Джерело: за даними сайту booking.com станом на 05.11.2021 p. [4]

MICE - послуги бізнес-сервісу, можливість оренди конфреренц-залу, організації ділових заходів, надають такі заклади Черкащини як: готель «Reikartz Aquadar» (м. Маньківка), готель «Optima» (м. Черкаси), готель «Україна» (м. Черкаси), готель «Cherkasy Palace» (колишній «Апельсин») (м. Черкаси), готель «Умань Плаза» (м. Умань), ГК «Водяники» (с. Водяники), Готель ««Parade Allure» (м. Жашків) та інші.

Особливим попитом та значним інтересом у відвідувачів користуються послуги SPAцентрів. Такі наявні у таких закладах як: готель «Reikartz Aquadar» (м. Маньківка), Relax park «Riverwood» (с. Мошни) та планується відкрити найближчим часом у ГК «Selena Family Resort».

В сучасних умовах розвитку інфрормаційних технологій та панування «ринку споживача» одним 3 найважливіших інструментів просування, позиціонування, а також забезпечення успіху готельних закладів $€$ мережа інтернет та спеціалізовані сайти (наприклад, booking.com, hotels24.ua тощо), що містять розгорнуту інфрормацію про заклад, а також дають можливість одразу порівняти з іншими пропозиціями, проаналізувати відгуки інших клієнтів та забронювати номер на обраний період. В рамках нашого дослідження нами було проаналізовано інформацію, що наведено на одному 3 найпопулярніших сайтів бронювання готелів booking.com, їх рейтинг, а також визначено представлення засобів розміщення, у мережі інтернет наявністю власних сайтів. Результати дослідження представлено у таблиці 2.
Проведений аналіз засвідчив популярність розташування готельних комплексів поблизу потужних спортивних осередків регіону у яких набуває розвитку спортивний туризм. Мова йде, перш за все, про готельний комплекс «Водяники», який розташований на однойменному гірськолижному курорті [14]. На території Жашківського кінного заводу розташовано готель ««Parade Allure» на 17 номерів [15], на території кінного клубу у передмісті Черкас розташовано готель «Вершник» на 29 номерів [11].

Іншою особливістю розвитку готельної інорраструктури Черкащини також $є$ розташування засобів розміщення вздовж річки Дніпро, що можна прослідкувати з рис. 1. Найяскравішими представниками таких готелів $€$ такі заклади як ГК «Selena Family Resort», ГК «Perlyna Resort», готель «Княжа Гора» та парк-готель «Тихий ліс».

В рамках дослідження проаналізуємо також діяльність зелених садиб на Черкащині. Дані заклади також $€$ аналогічними колективними засобами розміщення регіону. Їх точну кількість встановити складно, оскільки державні органи влади не обліковують дану категорію закладів в числі колективних засобів розміщення. За даними обласного дочірнього підприємства «Туризм» у 2011 році в регіоні налічувалася 21 зелена садиба; у 2013 році - 32 садиби. Середня завантаженість даних садиб (за інформацією власників) складає $60 \%$. Найрозвиненішими в цьому напрямку є Смілянський (8 садиб), Черкаський (6 садиб) та Канівський (6 садиб) райони [23]. Також в Україні створено та функціонує 
Таблиця 2

Представлення та рейтинг основних засобів розміщення Черкащини на сайті booking.com (станом на 12.10.2021 p) та у мережі інтернет

\begin{tabular}{|c|c|c|c|}
\hline Назва & Рейтинг & кіл-ть відгуків & Сайт \\
\hline Готель «Застава» & 9,4 & 248 & https://zastava.ua/ \\
\hline Готель «Ломо» & 9,3 & 185 & https://lomohotel.com.ua/index.php \\
\hline Готель «Optima» & 8,8 & 616 & https://reikartz.com/uk/hotels/cherkasy/ \\
\hline Готель «Меланія» & 8,9 & 982 & https://melania-hotel.business.site/ \\
\hline Готель «Україна» & 8,7 & 549 & https://ukraina-hotel.org/index ua.html \\
\hline Готель «Черкаси» & 8,2 & 456 & - \\
\hline Готель «Княжа Гора» & 8,6 & 248 & https://www.knyazhahora.com/ \\
\hline Готель «Вершник» & 8,5 & 139 & http://vershnyk.com.ua/ \\
\hline ГK «Selena Family Resort» & 8,4 & 107 & https://hotelselena.info/ \\
\hline Готель «Умань Palace» & 8,6 & 982 & $\begin{array}{l}\text { https://umanplaza.com.ua/hotels/hotel- } \\
\text { uman-plaza }\end{array}$ \\
\hline Готель «Parade Allure» & 8,3 & 35 & http://paradeallure.com/ \\
\hline $\begin{array}{l}\text { Готель «Cherkasy Palace» } \\
\text { (колишній «Апельсин» }\end{array}$ & 8,2 & 562 & https://hotelapelsin.com/ \\
\hline Готель «Reikartz Aquadar» & 8,1 & 264 & https://aquadar.reikartz.com/ru/ \\
\hline Готель «Фортеця» & 7,9 & 694 & http://fortecya.biz/ \\
\hline Готель «Дніпро» & 7,7 & 511 & https://hoteldnipro.org.ua/ru \\
\hline Готель «Нива» & 6,8 & 91 & - \\
\hline$\Gamma \mathrm{K}$ «Perlyna Resort» & 8,1 & 8 & http://perlyna.biz/ \\
\hline ГК «Водяники» & - & & $\begin{array}{l}\text { http://vodyaniki.com/index/otelnyj_ } \\
\text { kompleks_opisanie/0-27 }\end{array}$ \\
\hline Готель «Smile» & & & \\
\hline
\end{tabular}

Джерело: [4]

ГО «Всеукраїнська спілка зеленого сільського туризму», яка забезпечує сертифрікацію зелених садиб. Згідно з інорормацією даної організації в області фрункціонує 7 садиб: 1 садиба третьої категорії; одна садиба - 2 категорії; 3 садиби - третьої категорії та дві садиби базової категорії (табл. 3).
Зелені садиби на Черкащині зокрема та й в Україні в цілому - чудова альтернатива традиційним готелям, яких, на жаль, як засвідчив аналіз не достатньо в окремих туристичних осередках регіону та тематичне місце зупинки туристів екологічного та сільського (зеленого) туризму. Так на Чигиринщині - потужному туристичному

Таблиця 3

Зелені садиби Черкащини, що мають категорію (ГО «Українська гостинна садиба»)

\begin{tabular}{|c|c|c|c|c|}
\hline № & Назва & Власник & Адреса & Категорія \\
\hline 1 & Коло друзів & $\begin{array}{c}\text { Корнілов } \\
\text { Володимир Віталійович }\end{array}$ & с. Будище, Черкаський р-н &  \\
\hline 2 & Холодноярський зорепад & $\begin{array}{c}\text { Тимофрієв } \\
\text { Сергій Петрович }\end{array}$ & с. Сунки, Смілянський р-н & $\star \star *$ \\
\hline 3 & У пані Олі & Гугля Ольга Василівна & $\begin{array}{c}\text { с. Суботів, } \\
\text { Чигиринський р-н }\end{array}$ & * \\
\hline 4 & Дві сестри & $\begin{array}{c}\text { Савіцька } \\
\text { Любов Федорівна }\end{array}$ & $\begin{array}{c}\text { с. Суботів, } \\
\text { Чигиринський р-н }\end{array}$ & * \\
\hline 5 & Хата Берегині & $\begin{array}{c}\text { Островська } \\
\text { Леся Петрівна }\end{array}$ & $\begin{array}{c}\text { с. Мельники, } \\
\text { Чигиринський р-н }\end{array}$ & * \\
\hline 6 & Медова садиба & Прохач Ігор Петрович & $\begin{array}{c}\text { с. Суботів, } \\
\text { Чигиринський р-н }\end{array}$ & Базова \\
\hline 7 & Шполка & $\begin{array}{c}\text { Кожухов } \\
\text { Олександр Іванович }\end{array}$ & $\begin{array}{c}\text { с. Юрківка, } \\
\text { Звенигородський р-н }\end{array}$ & Базова \\
\hline
\end{tabular}


центрі Черкащини, «землі Богдана», одному 3 найбільш відвідуваних дестинації, немає засобів розміщення категорії туристичного готелю. Тому зелені садиби досить успішно виконують фрункції засобу розміщення у даній території.

ще одним різновидом аналогічних колективних засобів розміщення, що представлено в Черкаській області $€$ хостели. На жаль, їх точну кількість встановити не видається можливим. Втім, нами було систематизовано наявну у відкритих джерелах інфрормацію щодо діяльності хостелів у регіоні (табл. 4).

Переконані, щохостелів у Черкаській області значно більше. Втім, з огляду на їх здебільшого неофріційний характер фрункціонування, інорормації про них не багато. Окрім того, аналогами хостелів $€$ індивідуальні засоби розміщення численні квартири подобово.

Діяльність спеціалізованих засобів розміщення, що $є$ основою розвитку лікувальнооздоровчого туризму в Черкаській області характеризуються їх незначною кількістю. Всього у 2017 році в Черкаській області фрункціонував 41 заклад. Відзначимо, що кількість цих закладів з 2011 року зменшилася на 17 одиниць. Водночас, регіон у аналізованому 2017 році посідав 12 місце в Україні за кількістю спеціалізованих засобів розміщування.

Висновки. Таким чином, проведений аналіз рівня розвитку готельного господарства Черкаської області засвідчив, що регіон досить не погано забезпечений основними видами засобів розміщення. $€$ чотирьохзірковий готель, кілька трьох зіркових та безліч готельних комплексів, що в переважній більшості розташовуються вздовж Дніпра. Негативним моментом $€$ відсутність двозіркового готелю в обласному центрі та подібного роду закладів у великих туристичних осередках регіону (Канівщина, Чигиринщина). Готельна галузь Черкащини представлено також численними хостелами, спеціалізованими засобами розміщення, зеленими садибами. Готелі на Черка-

щині розташовані вкрай нерівномірно. Міста Черкаси та Умань містять найбільшу кількість засобів розміщення, натомість потужні туристичні центри, як то Канівщина, Чигиринщина, Звенигородщина - не надто забезпечені готелями та аналогічними засобами розміщення.

У аспекті забезпечення розвитку туристичної сорери регіону, в роботі було проаналізовано стан забезпечення засобами розміщення основних туристичних напрямків за видами туризму в регіоні. Так, добре забезпечені такі види туризму як гірськолижний (ГК «Водяники», с. Водяники), кінний (ГК «ParadeAllure», м. Жашків, готель «Вершник», м. Черкаси), діловий (готель «Дніпро», м. Черкаси, готель «Optima», м. Черкаси, готель «Україна», м. Черкаси та інші), велнес / лікувально-оздоровчий туризм (готель «Reikartz Aquadar», м. Маньківка), пляжно-купальний (ГК «Selena Family Resort», м. Черкаси, ГК «Perlyna Resort», м. Черкаси), фестивальний (готель «Княжа Гора», м. Канів), сільський (зелений) - безліччю зелених садиб та інші. Водночас, проблемними залишається питання забезпечення доступності номерного фонду для особливих категорій населення людей 3 інвалідністю. Проблемними також $€$ застарілість багатьох будівель та оснащення більшості готелів регіону.

Перспективними напрямами розвитку готельного господарства Черкащини вбачаємо впровадження інноваційних технологій - як на рівні управління (системи оперативного маркетингу), так і на рівні прийому відвідувачів (створення спеціальних баз даних постійних відвідувачів, інорормування їх про новинки) та інше. Важливим та досить пріоритетним $€$ також можливість побудови на території Черкащини готелю категорії «**», що прийматиме великі туристичні групи. Також перспективним вважаємо розвиток в області готелю екологічного спрямування. Таких закладів нині в Україні зовсім не багато, втім світова практика свідчить про значний інтерес клієнтів саме до такого роду закладів.

Таблиця 4

\section{Хостели в Черкаській області}

\begin{tabular}{|c|l|l|}
\hline № & \multicolumn{1}{|c|}{ Назва } & \multicolumn{1}{|c|}{ Адреса / p-н } \\
\hline 1 & «Swallow_House» & м. Черкаси, ж/д вокзал \\
\hline 2 & Перший хостел в Черкасах & м. Черкаси, вул. 30-річчя Перемоги, 22 \\
\hline 3 & Третій хостел Олени Кравцової в Черкасах & м. Черкаси, вул. Олени Теліги, 1 \\
\hline 4 & «Преміум» & м. Черкаси, бульвар Шевченка, 220, кв. 23 \\
\hline 5 & «енгуру» & м. Умань, вул. Кумановского, 41 \\
\hline 6 & «Davidoff» & м. Умань, вул. Мономаха, 29 \\
\hline 7 & «Berki-hostel» & м. Умань, вул. Пушкіна, 46 \\
\hline 8 & In Mordechai & м. Умань, вул. Гайдамацька, 5 \\
\hline
\end{tabular}




\section{СПИСОК ВИКОРИСТАНИХ ДЖЕРЕЛ:}

1. Власенко І. Готельне господарство у соціальній інсраструктурі країни. Вісник Київського національного торговельно-економічного університету. 2019. № 3. C. 85-97. URL: http://nbuv.gov.ua/UJRN/Vknteu_2019_3_9 (дата звернення: 24.04.2021).

2. Колективні засоби розміщування в місті Черкаси у 2019 році. Статистичний бюлетень. Головне управління статистики у Черкаській області. Черкаси, 2020. 16 с.

3. Колективні засоби розміщування в місті Черкаси у 2020 році. Статистичний бюлетень. Головне управління статистики у Черкаській області. Черкаси, 2021. 12 с.

4. Сайт бронювання готелів. URL: https://www.booking.com (дата звернення: 24.04.2021).

5. Сайт туристиних відгуків. URL: https://www.tripadvisor.ru/ (дата звернення: 24.04.2021).

6. Сайт готелю «Дніпро». URL: https://hoteldnipro.org.ua/ua (дата звернення: 24.04.2021).

7. Сайт готелю «Optima». URL: https://reikartz.com/uk/hotels/cherkasy/ (дата звернення: 24.04.2021).

8. Сайт готелю «Україна». URL: https://ukraina-hotel.org/index_ua.html (дата звернення: 24.04.2021).

9. Сайт готелю «Cherkasy Palace». URL: https://hotelapelsin.com/ (дата звернення: 24.04.2021).

10. Сайт готельного комплексу «SelenaFamily Resort». URL: https://hotelselena.info/ (датазвернення: 24.04.2021).

11. Сайт готелю «Вершник». URL: http://vershnyk.com.ua/ (дата звернення: 24.04.2021).

12. Сайт готельного комплексу «Perlyna Resort». URL: http://perlyna.biz/ (дата звернення: 24.04.2021).

13. Сайт готелю «Reikartz Aquadar». URL: https://aquadar.reikartz.com/uk/ (дата звернення: 24.04.2021).

14. Сайт готельного комплексу «Водяники». URL: http://vodyaniki.com/index/otelnyj_kompleks_opisanie/0-27 (дата звернення: 24.04.2021).

15. Сайт готелю «Parade Allure». URL: http://paradeallure.com/gostinica-parade-allure/ (дата звернення: 24.04.2021).

16. Сайт готелю «Княжа Гора». URL: https://www.knyazhahora.com/hotel (дата звернення: 24.04.2021).

17. Сайт готелю «Умань Плаза». URL: https://umanplaza.com.ua/hotels/hotel-uman-plaza (дата звернення: 24.04.2021).

18. Сайт готельно-ресторанного комплексу «Застава». URL: https://zastava.ua/ (датазвернення: 24.04.2021).

19. Сайт готелю «Меланія». URL: https://melania-uman.hotelmix.com.ua/ (дата звернення: 24.04.2021).

20. Сайт готелю «Ломо». URL: https://lomohotel.com.ua/about.php (дата звернення: 24.04.2021).

21. Сайт готелю «Фортеця». URL: http://fortecya.biz/ (дата звернення: 24.04.2021).

22. Вісім готелів в Україні отримали або підтвердили свої «зірки». 27.04.2021. URL: https://focus.ua/uk/ economics/481213-vosem-gostinic-v-ukraine-poluchili-ili-podtverdili-svoi-zvezdy (дата звернення: 24.04.2021).

23. Туризм (обласне дочірнє підприємство). URL: https://ck-oda.gov.ua/turyzm-oblasne-dochirnjepidpryjemstvo/ (дата звернення: 24.04.2021).

24. Сайт ГО «Спілка сільського зеленого туризму України» URL: https://www.greentour.com.ua/region/ cherkaska (дата звернення: 24.04.2021).

\section{REFERENCES:}

1. Vlasenko I. (2019) Hotelne hospodarstvo u sotsialnii infrastrukturi krainy [Hotel economy in the social infrastructure of the country]. Visnyk Kyivskoho natsionalnoho torhovelno-ekonomichnoho universytetu, no. 3, pp. 85-97. Available at: http://nbuv.gov.ua/UJRN/Vknteu_2019_3_9 (accessed 05 of November 2021).

2. Kolektyvni zasoby rozmishchuvannia v misti Cherkasy u 2019 rotsi (2020) [Collective accommodation in the city of Cherkasy in 2019]. Statystychnyi biuleten. Holovne upravlinnia statystyky u Cherkaskii oblasti. Cherkasy, 16 p.

3. Kolektyvni zasoby rozmishchuvannia v misti Cherkasy u 2020 rotsi (2021) [Collective accommodation in the city of Cherkasy in 2020]. Statystychnyi biuleten. Holovne upravlinnia statystyky u Cherkaskii oblasti. Cherkasy, 12 p.

4. Sait broniuvannia hoteliv [Hotel booking site]. Available at: https://www.booking.com (accessed 05 of November 2021).

5. Sait turystynykh vidhukiv [Website of tourist reviews]. Available at: https://www.tripadvisor.ru/ (accessed 05 of November 2021).

6. Sait hoteliu «Dnipro» [Website of the hotel "Dnipro"]. Available at: https://hoteldnipro.org.ua/ua (accessed 05 of November 2021).

7. Sait hoteliu «Optima» [Website of the hotel "Optima"]. Available at: https://reikartz.com/uk/hotels/cherkasy/ (accessed 05 of November 2021).

8. Sait hoteliu «Ukraina» [Website of the hotel "Ukraine"]. Available at: https://ukraina-hotel.org/index_ua.html (accessed 05 of November 2021). 
9. Sait hoteliu «Cherkasy Palace» [Website of the hotel "Cherkasy Palace"]. Available at: https://hotelapelsin.com/ (accessed 05 of November 2021).

10. Sait hotelnoho kompleksu «Selena Family Resort» [Website of the hotel complex "Selena Family Resort"]. Available at: https://hotelselena.info/ (accessed 05 of November 2021).

11.Sait hoteliu «Vershnyk» [Website of the hotel "Rider"]. Available at: http://vershnyk.com.ua/ (accessed 05 of November 2021).

12. Sait hotelnoho kompleksu «Perlyna Resort» [Website of the hotel complex "Perlyna Resort"]. Available at: http://perlyna.biz/ (accessed 05 of November 2021).

13. Sait hoteliu «Reikartz Aquadar» [Website of the hotel "Reikartz Aquadar"]. Available at: https://aquadar.reikartz.com/uk/ (accessed 05 of November 2021).

14. Sait hotelnoho kompleksu «Vodianyky» [Website of the hotel complex "Water"]. Available at: $h$ ttp://vodyaniki.com/index/otelnyj_kompleks_opisanie/0-27 (accessed 05 of November 2021).

15. Sait hoteliu «Parade Allure» [Website of the hotel "Parade Allure"]. Available at: http://paradeallure.com/ gostinica-parade-allure/ (accessed 05 of November 2021).

16. Sait hoteliu «Kniazha Hora» [Website of the hotel "Knyazha Gora"]. Available at: https://www.knyazhahora.com/ hotel (accessed 05 of November 2021).

17. Sait hoteliu «Uman Plaza» [Website of the hotel "Uman Plaza"]. Available at: https://umanplaza.com.ua/ hotels/hotel-uman-plaza (accessed 05 of November 2021).

18. Sait hotelno-restorannoho kompleksu «Zastava» [Website of the hotel and restaurant complex "Zastava"]. Available at: https://zastava.ua/ (accessed 05 of November 2021).

19. Sait hoteliu «Melaniia» [Website of the hotel "Melania"]. Available at: https://melania-uman.hotelmix.com.ua/ (accessed 05 of November 2021).

20. Sait hoteliu «Lomo» [Website of the hotel "Lomo"]. Available at: https://lomohotel.com.ua/about.php (accessed 05 of November 2021).

21. Sait hoteliu «Fortetsia» [Website of the hotel "Fortress"]. Available at: http://fortecya.biz/ (accessed 05 of November 2021).

22. Visim hoteliv v Ukraini otrymaly abo pidtverdyly svoi "zirky" [Eight hotels in Ukraine have received or confirmed their "stars"]. 27.04.2021. Available at: https://focus.ua/uk/economics/481213-vosem-gostinic-vukraine-poluchili-ili-podtverdili-svoi-zvezdy (accessed 05 of November 2021).

23. Turyzm (oblasne dochirnie pidpryiemstvo) [Tourism (regional subsidiary)]. Available at: https://ck-oda.gov.ua/ turyzm-oblasne-dochirnje-pidpryjemstvo/ (accessed 05 of November 2021).

24. Sait HO «Spilka silskoho zelenoho turyzmu Ukrainy» [Website of the NGO "Rural Green Tourism Union of Ukraine"]. Available at: https://www.greentour.com.ua/region/cherkaska (accessed 05 of November 2021). 